\title{
Differential responses of aquatic and aerobic forms of Echinochloa crus-galli (L.) Beauv. and E. colona (L.) Link. by morpho-physiological and molecular analysis
}

\author{
Abdel-Hamid A. Khedr, Mamdouh M. Serag, Heba E. Shaaban*, \\ Gaber M. Abogadallah
}

Department of Botany, Faculty of Science, Damietta University, 33115 Damietta, Egypt

Received: 2 October 2016

Accepted: 28 February 2017

Published online: 14 March 2017

\begin{abstract}
Echinochloa crus-galli and E. colona are serious weeds around the world. Morphological and biochemical features of aquatic and aerobic forms of both species were investigated experimentally by transplanting the seedlings reciprocally between water-saturated and aerobic soils (70\% field capacity). When the plants were grown in water-saturated soil, a significant decrease in tiller height was observed in E. crus-galli, but not in E. colona. Upon growing the plants in aerobic soil, internode length and spike dry weight increased significantly in E. crus-galli, but decreased significantly in E. colona. Growth under aerobic condition caused a significant increase in PEPC/Rubisco ratio, but a significant decrease was observed under water-saturated conditions. When E. crus-galli was transplanted in aerobic soil, several forms of peroxidase were upregulated. Contrarily, in E. colona peroxidase isoforms did not respond to habitat change. Gene expression of $A D H$ in E. colona was constitutive at a fairly high level under native habitats then enhanced with reversing habitat that caused anoxic and mild drought conditions. Both species tend to grow faster under aerobic conditions by modifying the photosynthetic machinery and capacity of scavenging of reactive oxygen species. Furthermore, ADH appears to play a role in supporting growth under water-saturated conditions.
\end{abstract}

Keywords: $A D H$, Echinochloa, habitat alteration, Rubisco, PEPC

\section{Introduction}

The genus Echinochloa includes serious weeds in agriculture (Holm et al. 1977). Echinochloa crus-galli (L.) Beauv is a $\mathrm{C} 4$ weed that grows essentially in paddy fields worldwide. It has a possibility for reclamation of saline soil in Egypt (Abogadallah and Quick 2009). Echinochloa colona, a vigorous C4 annual species, is one of the most serious grass weeds in rice (Rao et al. 2007). More than 60 countries have reported it as a weed problem in 35 crops including rice, maize, sorghum, sugarcane, cotton, and peanuts (Holm et al. 1991). E. colona can reduce the yield of direct-seeded rice up to $76 \%$ at a density of 280 plants $\mathrm{m}^{-2}$ (Mercado and Talatala 1977), whereas E. crus-galli was reported to reduce

* Corresponding author: Heba E. Shaaban

e-mail: heba.shaaban152@gmail.com 
Khedr et al.

the yield by $57 \%$ at a density of 9 plants $\mathrm{m}^{-2}$ (Maun and Barrett 1986). The two weedy species are also known to grow vigorously in semi-dry (aerobic) habitats such as cotton fields and therefore appear to be adapted to grow in a wide range of habitats in terms of soil water content.

The strongly variable dormancy of E. crus-galli seeds confers to this species a selective advantage, for example allowing the germination and growth of cohorts in periods not concurrent with herbicide spraying (Vidotto et al. 2007). Understanding the mechanisms controlling seeds germination and plant growth of these weeds under different field conditions is essential to develop efficient weed management procedures, the conditions of aerobic soil were similar to cotton field and water-logging soil was similar to rice field conditions.

Plants react with changes in the environment by phenotypic plasticity, where plant responses in different environments were due to a reaction norm. Plant response in populations of different habitat depends on the interplay of the genetic architecture of populations with interactions of genotypes with the environment (Schlichting and Pigliucci 1998) and adaptation to local conditions (Linhart and Grant 1996).

Biotic stresses are major threats to plant growth and crop production (Taji et al. 2004). Plants always have to overcome the stress to survive. Mechanisms of resistance that allow plants to tolerate the stress are activated either by acclimatization (an adjustment of individual organisms in response to the change in environmental factors) or by adaptations (genotypically determined stress-resistance traits that are expressed whether a plant is stressed or not) (Bray et al. 2000).

Water logging and submerging lead to a reduction in gas exchange between plant tissue and atmosphere because the gasses diffuse 10000 times more slowly in water than in air (Armstrong 1979). This leads to anoxic or hypoxic conditions around the roots, which are major determinants of the adverse effects of flooding.

Alcohol dehydrogenase ( $A D H, \mathrm{EC}$ 1.1.1.1) is an enzyme that converts pyruvate into ethanol in the fermentation pathway in organisms extended from bacteria to animals and plants. Most alcohol dehydrogenases that have been characterized at the gene level in plants belong to three groups of dimeric, zinc-containing enzymes: NADC-dependent 'classical' alcohol dehydrogenases active on ethanol (EC 1.1.1.1); NADPC-dependent cinnamyl alcohol dehydrogenases active in lignin biosynthesis (EC 1.1.1.195); and formaldehyde-active class III alcohol dehydrogenases D S-hydroxy methyl glutathione dehydrogenases (EC 1.2.1.1; Shafqat et al. 1996). ADH has many roles, including plant cell survival during low oxygen stress in waterlogged roots, in dry seeds, in anoxic or hypoxic conditions, and in anaerobically treated seeds and shoots (Chang and Meyerowitz 1986). ADH activity increases under different stress conditions, including water-logging (Crawford 1977). Changes in the levels of enzyme activity have been reported within a day under hypoxic conditions and may occur more quickly under anoxic conditions (Keeley and Franz 1979).

The aim of this work was to understand how E. crus-galli and E. colona adapt to grow profusely in aquatic (paddy fields) and aerobic soils, first by studying the morphological traits, physiological analysis including phosphoenolpyruvate carboxylase (PEPC), ribulose-1,5 bisphosphate carboxylase oxygenase (Rubisco) and peroxidase (POD), and second by studying the gene expression of alcohol dehydrogenase $(A D H)$.

\section{Materials and Methods}

\subsection{Experimental design}

The seeds of the two species E. crus-galli and E. colona used in this study were collected from paddy and cotton fields. The seeds from paddy or cotton fields were sown in a greenhouse in two groups at different habitats (aquatic and aerobic) into blocks $50 \times 50 \mathrm{~cm}$ in June 2012. Greenhouse conditions 
Khedr et al.

were: $1550 \mu$ mole $\mathrm{m}^{-2} \mathrm{~s}^{-1}$ maximum light intensity, $28 / 19^{\circ} \mathrm{C}$ day/night temperature, $14 \mathrm{~h}$ photoperiod, $70 \%$ relative humidity, $4.97 \mathrm{~m} \mathrm{~s}^{-1}$ wind speed. After $30 \mathrm{~d}$ from the first irrigation, the plants were transplanted from blocks into $3.0 \mathrm{~L}$ pots containing $2.5 \mathrm{~kg}$ of clay soil. The pots were either kept saturated with water or watered every day so that the soil water content was maintained at $70 \%$ field capacity (FC) (aerobic pots). Each pot contained one plant, with 10 replicates for each treatment. Four treatments were included for each species: (1) plants from aquatic habitat transplanted into aquatic pots, (2) plants from aquatic habitat transplanted into aerobic pots, (3) plants from aerobic habitat transplanted into aerobic pots and (4) plants from aerobic habitat transplanted into aquatic pots. The plants were maintained for two months in pots and watered every day so that the aquatic pots were kept covered with $2-5 \mathrm{~cm}$ of water and those in aerobic pots were maintained in soil with $70 \% \mathrm{FC}$.

\section{Harvesting of the plants}

At the end of the experiment (after three months), the plants were removed from the pots, washed with deionized water and plotted between dry layers of tissue. Different Plant parts (leaf, root, stem and spike) were collected for morphological traits as described below. Leaf samples from each treatment were collected, immediately frozen in liquid nitrogen and stored at $-80^{\circ} \mathrm{C}$ until used for biochemical and molecular analyses.

\subsection{Morphological traits}

The morphological investigated in this study were: number of tillers, length of tiller, number of nodes, length of internodes, length of leaf sheath, length of spike, fresh weight of spike (spike FW), dry weight of spike (spike DW), water content of spike (spike WC), fresh weight of shoot (shoot FW), dry weight of shoot (shoot DW), water content of shoot (shoot WC), fresh weight of root (root FW), dry weight of root (root DW) and water content of root (root WC). The leaf area (A) was calculated from the formula: $\mathrm{A}=[(\mathrm{L}+\mathrm{W})+\mathrm{K}]$, where $\mathrm{L}$ is leaf length measured from leaf tip of the basal lobe, and W is the maximum width of the leaf, $\mathrm{k}=0.905$ (Kemp 1960).

After fresh weights of shoots were recorded, they were dried at $80^{\circ} \mathrm{C}$ in the oven for $48 \mathrm{~h}$. The water contents were calculated on fresh weight basis. Three replicates were used for each treatment.

\subsection{Physiological Analysis}

\section{Measurement of PEPC, Rubisco and peroxidase}

Leaf soluble proteins were extracted by grinding the frozen tissue in $50 \mathrm{mM}$ sodium phosphate buffer containing $2 \mathrm{mM}$ EDTA and $5 \mathrm{mM} \beta$-mercapto ethanol. The debris was removed by centrifugation at $12,000 \mathrm{rpm}$ for $10 \mathrm{~min}$ at $4^{\circ} \mathrm{C}$. The protein concentration was determined as described by Bradford (1976). The proteins were resolved as described by Laemmlli (1970) by using the BioRad Mini Protean 3 (BioRad laboratories, Hercules, CA, USA). Acrylamide concentration in the resolving gel was $11 \%$ and in the stacking gel was $5 \% .20 \mu \mathrm{g}$ of protein was loaded onto each lane. The proteins were resolved at $100 \mathrm{~V}$ for $90 \mathrm{~min}$. The gels were stained with brilliant blue R-250 (BioRad) and then destained with $20 \%$ methanol, scanned and used for PEPC and Rubisco quantification by measuring the band volumes by using Image Studio software V 3.1 (Li-Cor, USA).

\section{Peroxidase enzyme}

The proteins were resolved on $11 \%$ non-denaturing acrylamide gels as described by Laemmlli (1970) without sodium dodecyl sulfate in all solutions. $20 \mu \mathrm{g}$ proteins were loaded onto each lane and proteins were resolved using the Bio-Rad Mini protean 3 unit (BioRad Laboratories Inc, Hercules, CA). The gels were run for about $90 \mathrm{~min}$ at $4{ }^{\circ} \mathrm{C}$ at $80 \mathrm{~V}$. The gels were washed briefly with distilled water. POD isoforms were detected by incubating the gels in staining solution containing $2 \mathrm{mM}$ 
Khedr et al.

diaminobenzidine (DAB), $50 \mathrm{mM}$ acetate buffer ( $\mathrm{pH} 5.0$ ) and $0.03 \%$ (v/v) $\mathrm{H}_{2} \mathrm{O}_{2}$ for about $45 \mathrm{~min}$. When the bands were clearly visible, the gels were washed with distilled water then dried and scanned (Seevers et al. 1971).

\subsection{Quantification of alcohol dehydrogenase (ADH) by semi-quantitative RT-PCR}

Total RNA was extracted from about $50 \mathrm{mg}$ frozen leaves using TRI-reagent (Sigma, UK) according to the manufacture's protocol. DNA contamination avoided by using the DNA-free kit (Ambion, UK) in extracted RNA for $30 \mathrm{~min}$ at $37^{\circ} \mathrm{C}$. Poly A tail mRNA was isolated by reacting $2 \mu 1$ of oligodT(18) with $10 \mu \mathrm{l}$ of RNA and $3 \mu \mathrm{l}$ RNase and DNase free $\mathrm{H}_{2} \mathrm{O}$ for $5 \mathrm{~min}$ at $70^{\circ} \mathrm{C}$ then the reaction was terminated on ice for $2 \mathrm{~min}$. The reverse transcription was conducted by using MMLVreverse transcription kit according to the supplier's recommendations (Promega, UK). The Primers were designed to recognize conserved regions resulting from the alignment of the characterized genes in other species that are related to E. crus-galli and E. colona. The primers used for amplifying ADH and 18S rRNA are listed in Tab. 1. The PCR conditions were as follows: initial denaturation at $94^{\circ} \mathrm{C}$ for 3 min, followed by 35 and 45 cycles of denaturation at $94^{\circ} \mathrm{C}$ for $30 \mathrm{~s}$, annealing at $50^{\circ} \mathrm{C}$ for $30 \mathrm{~s}$ and extension at $72^{\circ} \mathrm{C}$ for $50 \mathrm{~s}$, the number of PCR cycles was optimized to show the maximal differences among samples within the linear phase of amplification. The cycle numbers and conditions were determined to avoid the saturation of DNA. PCR products were resolved by electrophoresis on $1 \%$ agarose gels, stained with ethidium bromide in $1 \mathrm{X}$ TAE (Tris-acetic acid-EDTA) using Bio- Rad equipment and visualized and documented using Trans illuminator UViTec. The band volumes were measured by using Lab Image V 3.1 (Li-Cor, USA) software. The measurements were normalized for equal $18 \mathrm{~S}$ rRNA bands.

Tab. 1 Primer pairs and their Amplified fragment Size used for amplifying $A D H$ gene.

\begin{tabular}{cccc}
\hline Serial no. & Forward primer 5 3 & Reverse primer 5 3 & $\begin{array}{c}\text { Amplified } \\
\text { fragment } \\
\text { size (bp) }\end{array}$ \\
\hline Primer I & ATGAAGCTGGAGGGATTGTG & CATTCAACACTGCGGTCAAC & $\mathbf{6 0 7}$ \\
Primer II & ATGAAGCTGGAGGGATTGTG & GTTGCCAGTGCATTCAACAC & $\mathbf{6 1 7}$ \\
18S rRNA & CCACCCATAGAATCAAGAAAGAG & GCAAATTACCCAATCCTGAC & \\
\hline
\end{tabular}

\subsection{Statistical analysis}

Each measurement was repeated three times. In order to compare between samples, one-way ANOVA was performed using SPSS 18.0. Significant differences were tested at a significance level of 0.05 .

\section{Results}

\subsection{Effects of reversing habitats on plant growth}

Compared to treatment 1, reversing the habitat of E. crus-galli from aquatic to aerobic (treatment 2), led to no significant changes in shoot FW, shoot WC, root FW, root DW and root WC. However, a significant change in shoot DW was recorded where it increased by $29.89 \%$. E. colona showed significant changes in root FW and root DW where it increased by 31\%, 2.45 folds, respectively, but root WC decreased by $23.47 \%$.

Compared to treatment 3, Reversing the habitat from aerobic to aquatic (treatment 4) (waterlogging stress) showed insignificant change in all the studied parameters of E. crus-galli, while $E$. 
Khedr et al.

colona showed significant changes in shoot $\mathrm{FW}$, shoot DW and root WC and increased by $97.4 \%, 2$ folds and $10.69 \%$, respectively, under water-logging stress (Figs. $1 \mathrm{~A}, \mathrm{~B}, \mathrm{C}, \mathrm{D}, \mathrm{E}$ and F).

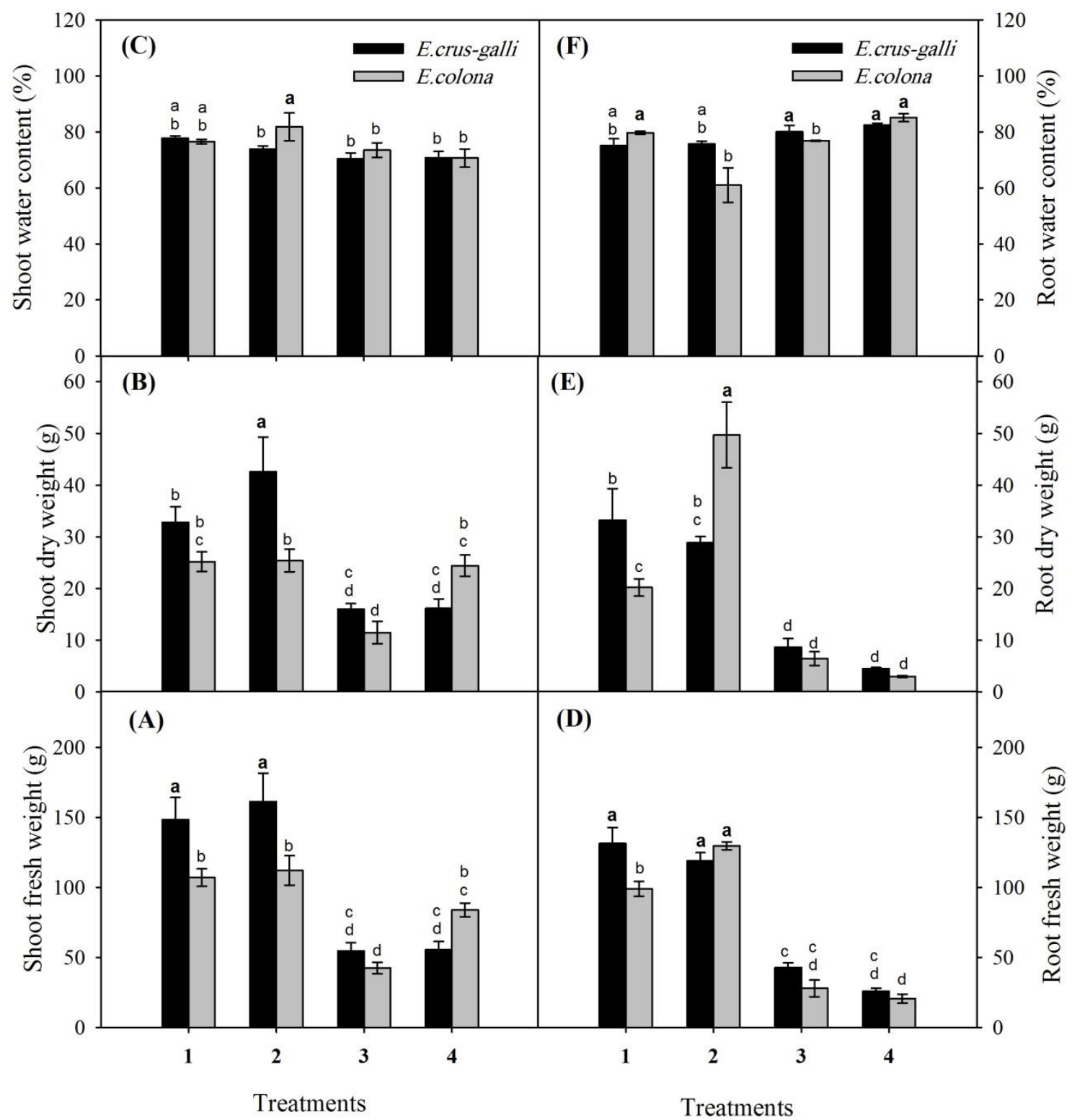

Fig. 1 Effect of different treatments 1: Wet, 2: Reversed to semi-dry, 3: Semi-dry, 4: Reversed to wet on (A: Shoot fresh weight, B: Shoot dry weight, C: Shoot water content, D: Root fresh weight, E: Root dry weight, F: Root water content) of E. crus-galli and E. colona. Data is mean $\pm \mathrm{SE}$ bars labeled with different letters are significantly different at $\mathrm{P}<0.05$.

\subsection{Morphological traits}

In treatment 2, the number of tillers, nodes and spike length of E. crus-galli showed no significant change, while the length of tillers, internode and leaf sheath increased significantly by $50.4 \%, 55 \%$ and $21 \%$ respectively, but leaf area significantly decreased by $19.8 \%$. In E. colona the lengths of tillers, internodes, leaf sheath and spike decreased significantly by $18.78 \%, 24.5 \%, 21 \%$ and $35.5 \%$ respectively, and the number of tillers increased significantly by $55.9 \%$.

In treatment $4, E$. crus-galli the significant length of tillers significantly increased by $24.73 \%$, but E. colona showed significant increase in the length of leaf sheath by $38.98 \%$ (Table 2). Treatment 2 of $E$. crus-galli significantly increased spike FW and spike DW by $87.8 \%$ and 2.8 folds, respectively, 
Khedr et al.

and spike WC significantly decreased by $23 \%$, while reversing the habitat from aerobic to aquatic did not affect the spike parameters (Tab. 3)

Tab. 2 Effect of different treatments 1: Wet, 2: Reversed to semi-dry, 3: Semi-dry, 4: Reversed to wet on (No. of tiller, Length of tillers, No. of node, Internode length, Leaf sheath Length and leaf area) of E. crus-galli and E. colona. Data is mean $\pm \mathrm{SE}$ labeled with different letters are significantly different at $\mathrm{P}<0.05$.

\begin{tabular}{|c|c|c|c|c|c|c|c|c|}
\hline \multirow{2}{*}{ Parameters } & \multicolumn{4}{|c|}{ E. crus-galli } & \multicolumn{4}{|c|}{ E. colona } \\
\hline & $\mathbf{1}$ & 2 & 3 & 4 & 1 & 2 & 3 & 4 \\
\hline \multirow{2}{*}{ Tillers (\#) } & 18.3 & 25.6 & 12.7 & 9.0 & 22.6 & 35.3 & 17.7 & 22.0 \\
\hline & $\pm 0.8^{\mathrm{bcd}}$ & $\pm 1.8^{\mathrm{bc}}$ & $\pm 1.2^{\mathrm{cd}}$ & $\pm 0.6^{\mathrm{d}}$ & $\pm 3.0^{\mathrm{bc}}$ & $\pm 1.4^{\mathrm{a}}$ & $\pm 2.3^{\mathrm{b}}$ & $\pm 3.0^{\mathrm{bc}}$ \\
\hline \multirow{2}{*}{ Tillers L (cm) } & 72.9 & 109.7 & 98.0 & 73.8 & 113.7 & 92.3 & 70.1 & 79.1 \\
\hline & $\pm 9.1^{\mathrm{e}}$ & $\pm 7.5^{\mathrm{ab}}$ & $\pm 8.1^{\mathrm{abc}}$ & $\pm 2.9^{\mathrm{de}}$ & $\pm 2.8^{\mathrm{a}}$ & $\pm 7.6^{\mathrm{bcd}}$ & $\pm 5.4^{\mathrm{e}}$ & $\pm 3.6^{\text {cde }}$ \\
\hline \multirow{2}{*}{ Node (\#) } & 6.0 & 6.7 & 6.7 & 6.3 & 6.0 & 6.7 & 7.2 & 7.0 \\
\hline & \pm 0.6 & \pm 0.3 & \pm 0.3 & \pm 0.3 & \pm 0.6 & \pm 0.3 & \pm 0.2 & \pm 0.6 \\
\hline \multirow{2}{*}{ Internode L $(\mathrm{cm})$} & 9.6 & 14.8 & 12.9 & 10.8 & 16.0 & 12.1 & 9.2 & 10.9 \\
\hline & $\pm 0.9^{\mathrm{de}}$ & $\pm 0.6^{\mathrm{ab}}$ & $\pm 1.2^{\mathrm{bc}}$ & $\pm 0.3^{\text {cde }}$ & $\pm 0.7^{\mathrm{a}}$ & $\pm 1.5^{\mathrm{cd}}$ & $\pm 0.8^{\mathrm{e}}$ & $\pm 0.7^{\text {cde }}$ \\
\hline \multirow{2}{*}{ Leaf L (cm) } & 14.0 & 11.0 & 9.9 & 10.5 & 9.7 & 7.6 & 6.2 & 8.6 \\
\hline & $\pm 1.0^{\mathrm{a}}$ & $\pm 0.8^{\mathrm{b}}$ & $\pm 0.4^{\mathrm{bc}}$ & $\pm 0.4^{\mathrm{b}}$ & $\pm 0.4^{\mathrm{bc}}$ & $\pm 0.5^{\mathrm{de}}$ & $\pm 0.3^{\mathrm{e}}$ & $\pm 0.5^{\mathrm{cd}}$ \\
\hline \multirow{2}{*}{ Leaf area $\left(\mathrm{cm}^{2}\right)$} & 32.9 & 26.7 & 26.5 & 28.4 & 16.4 & 13.9 & 12.3 & 14.2 \\
\hline & $\pm 2.5^{\mathrm{a}}$ & $\pm 1.1^{\mathrm{b}}$ & $\pm 1.4^{\mathrm{b}}$ & $\pm 1.1^{\mathrm{b}}$ & $\pm 0.9^{c}$ & $\pm 0.8^{\mathrm{cd}}$ & $\pm 0.2^{\mathrm{d}}$ & $\pm 1.4^{\mathrm{cd}}$ \\
\hline \multirow{2}{*}{ Spike L (cm) } & 12.9 & 14.4 & 13.3 & 13.7 & 14.7 & 9.49 & 9.04 & 11.4 \\
\hline & $\pm 0.6^{\mathrm{ab}}$ & $\pm 1.18^{\mathrm{a}}$ & $\pm 0.94^{\mathrm{ab}}$ & $\pm 0.2^{\mathrm{ab}}$ & $\pm 1.16^{\mathrm{a}}$ & $\pm 0.79^{\mathrm{c}}$ & $\pm 1.03^{\mathrm{c}}$ & $\pm 0.6^{\mathrm{cb}}$ \\
\hline
\end{tabular}

Tab. 3 Effect of different treatments 1: Wet, 2: Reversed to semi-dry, 3: Semi-dry, 4: Reversed to wet on (Spike Fresh Weight, Spike Dry Weight and Spike Water Content) of E. crus-galli. Data is Means \pm SE labeled with different letters are significantly different at $\mathrm{P}<0.05$.

\begin{tabular}{ccccc} 
& \multicolumn{4}{c}{ E. crus-galli } \\
\cline { 2 - 5 } Parameters & $\mathbf{1}$ & $\mathbf{2}$ & $\mathbf{3}$ & $\mathbf{4}$ \\
\hline Spike FW. (g) & $1.1 \pm 0.11^{\mathrm{b}}$ & $2.0 \pm 0.40^{\mathrm{a}}$ & $1.0 \pm 0.09^{\mathrm{b}}$ & $0.09 \pm 0.6^{\mathrm{ab}}$ \\
Spike DW. (g) & $0.34 \pm 0.09^{\mathrm{c}}$ & $0.96 \pm 0.19^{\mathrm{a}}$ & $0.52 \pm 0.04^{\mathrm{bc}}$ & $0.76 \pm 0.08^{\mathrm{ab}}$ \\
Spike WC. (\%) & $69.1 \pm 5.5^{\mathrm{a}}$ & $53.2 \pm 0.39^{\mathrm{b}}$ & $49.3 \pm 1.06^{\mathrm{b}}$ & $49.2 \pm 1.43^{\mathrm{b}}$ \\
\hline
\end{tabular}

\subsection{Physiological analyses}

\section{PEPC and Rubisco contents}

Treatment 2 in both E. crus-galli and E. colona, PEPC and Rubisco protein levels were significantly decreased by $(22.78 \%$ and $97.3 \%)$ and $(57.21 \%$ and $61.74 \%)$, respectively, whereas the PEPC/Rubisco ratio was increased by 28.22 folds and $11.78 \%$, respectively. Treatment 4 in both $E$. crus-galli and E. colona, PEPC protein level and PEPC/Rubisco ratio were significantly decreased by (53.75\% and $83.57 \%)$ and (32.97\% and 56.25\%), respectively. Rubisco protein level was increased in both species by 2.93 folds and $53.75 \%$, respectively (Fig.2 A and 2 B).

\section{Peroxidase Enzyme}

Three peroxidase isozymes were detected on native acrylamide gels. In E. crus-galli, treatment 2 upregulated the isozyme $\mathrm{P} 4$ while treatment 4 caused the disappearance of $\mathrm{P} 4$ and only two isozymes 
Khedr et al.

were present P1and P2. In E. colona treatments 2 and 4 did not affect peroxidases isozymes where only 3 isozymes were present in all treatments (P1, P3 and P5) (Fig.3).

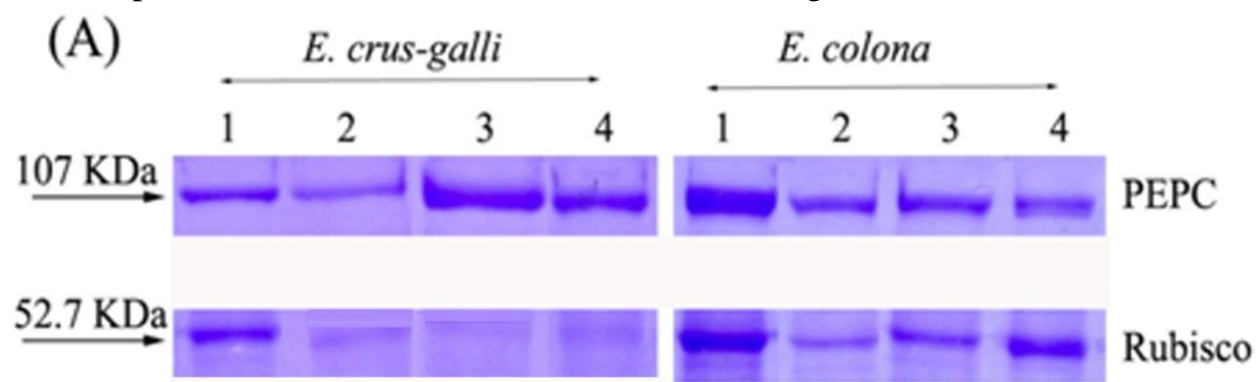

Fig. 2A SDS-page shows the protein bands of PEPC and Rubisco in E. crus-galli and E. colona in different treatments 1: Wet, 2: Reversed to semi-dry, 3: Semi-dry, 4: Reversed to wet.

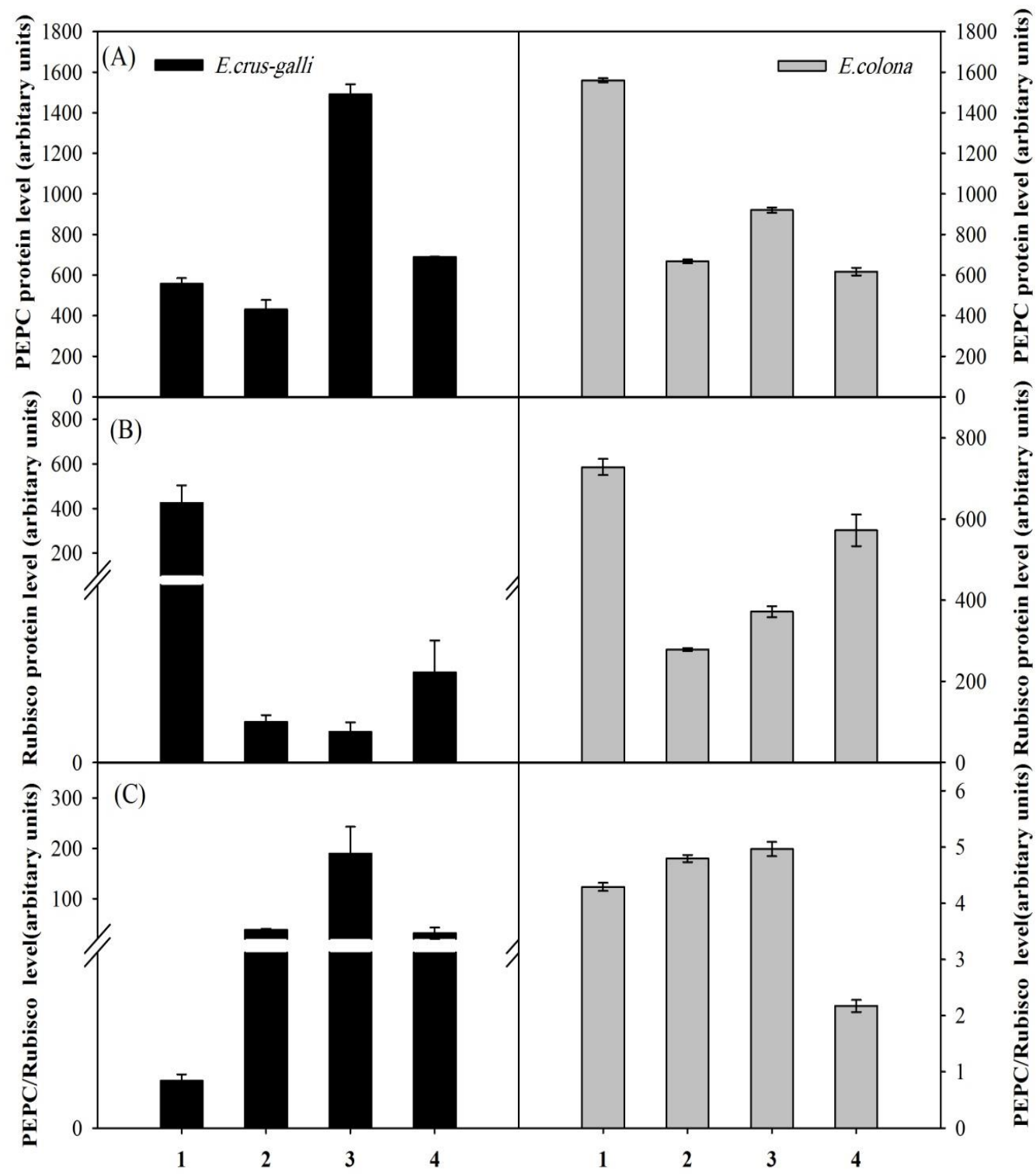

Treatments

Fig. 2B Effect of different treatments 1: Wet, 2: Reversed to semi-dry, 3: Semi-dry , 4: Reversed to wet on PEPC (A), Rubisco (B), and PEPC/Rubisco (C) level content in E. crus-galli and E. colona . Bars are means \pm SE. 
Khedr et al.

\subsection{Expression of Alcohol Dehydrogenase $(A D H)$ in response to habitat alteration}

The transcript level of $A D H$ in E. colona increased in plants grown in reversed habitats compared to those transplanted into similar habitats, where it increased by 8.48 folds in treatment 2 and also increased by 5.47 folds in treatment 4 . The transcripts of $A D H$ in $E$. crus-galli was only detectable in plants grown in reversed to aquatic habitat (Fig.4). The transcripts of $A D H$ in roots were not detected in both E. colona and E. crus-galli.

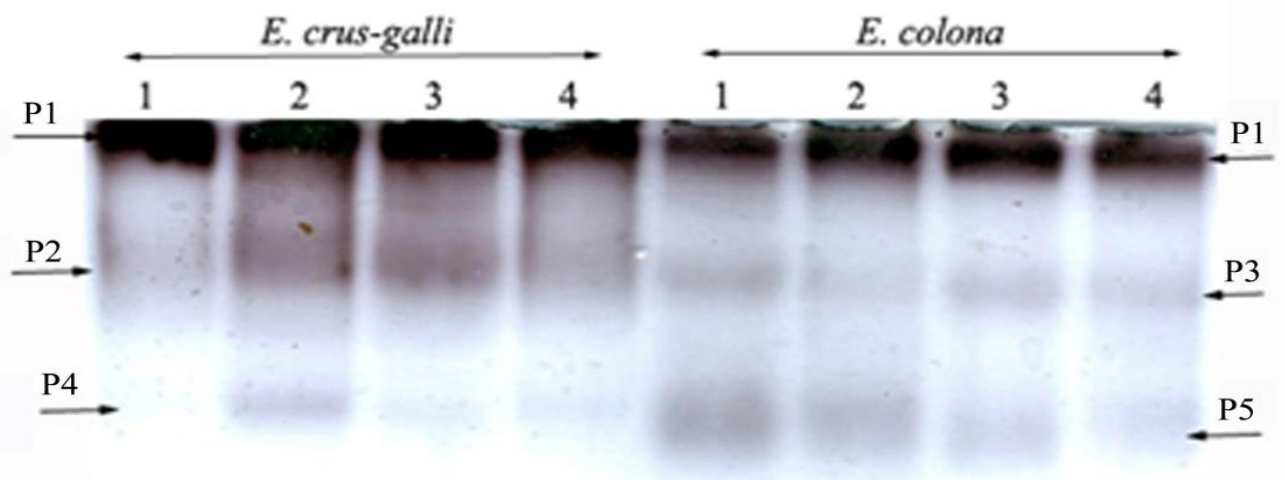

Fig. 3 Activity gels of leaf peroxidaes under reversed habitat treatments (1, 2, 3 and 4 are different habitats) 1: Wet, 2: Reversed to semi-dry, 3: Semi-dry, 4: Reversed to wet to illustrate Peroxidase isozymes in E. crus-galli and E. colona.

(A)

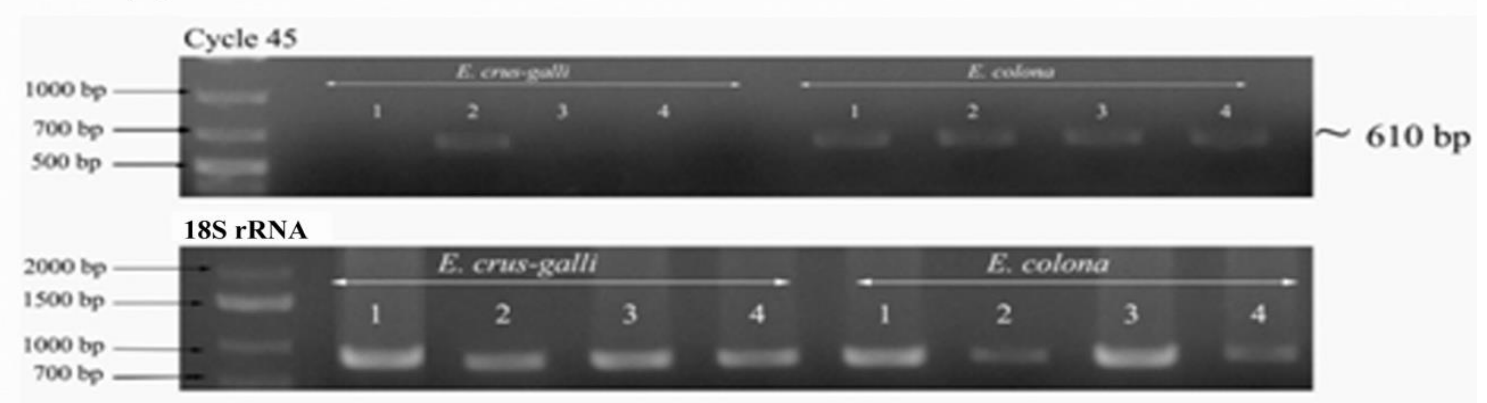

(B)

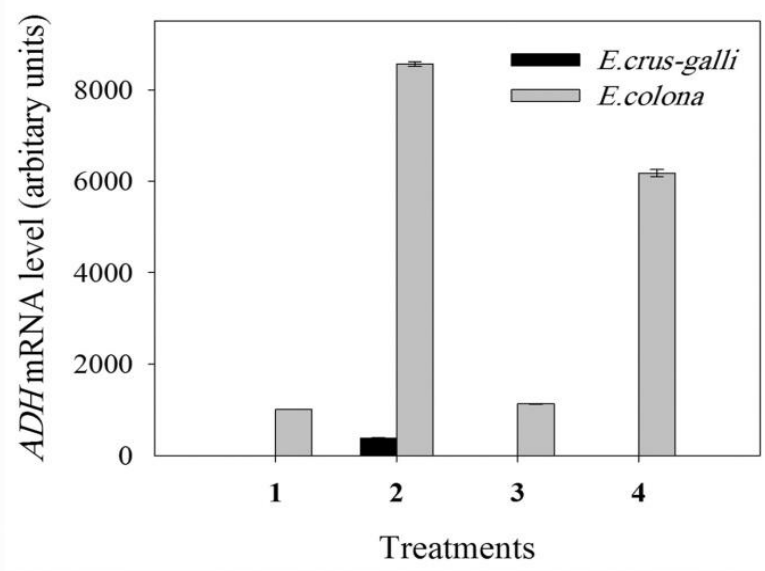

Fig. 4 Semi-quantitative RT-PCR of E. crus-galli and E. colona ADH under Reversed habitat treatment (1, 2, 3 and 4 are different habitats). 1: Semi-dry 2: Reversed to wet 3: Wet 4: Reversed to semi-dry. (A): Ethidium bromide-stained gels. (B) Quantification of expression in terms of band volumes at cycle 45. 
Khedr et al.

\section{Discussion}

In the present work, E. crus-galli and E. colona were exposed to mild drought (reversing the growth habitat from aquatic to aerobic, treatment 2), and water-logging (reversing the growing habitat from aerobic to aquatic, treatment 4). Both species showed tolerance to water-logging and mild drought. Waterlogging did not affect the total biomass of E. crus-galli and E. colona, while mild drought slightly promoted the growth of E. colona (Fig. 1). Biomass of E. crus-galli was significantly increased when exposed to mild drought while E. colona was significantly decreased when exposed to waterlogging.

Growing of both species under mild drought and water-logging condition did not cause any significant change in the number of tillers, while the sensitive plants to waterlogging like wheat showed declined tillering (Cannell et al. 1980). When the plants were grown under water-logging, a significant decrease in tiller length was observed in E. crus-galli compared to the other which grown in native aerobic habitat, but no significant change was found in E. colona. Striker (2012) predicted that shoot morphology in graminaceous species was altered in flooding soil due to the close functional interdependence between both of them, where tolerant species were often taller than others grown in non-flooded soil. These responses were characterized also in the dicotyledonous Rumex palustris (Heydarian et al. 2010).

Spike DW of E. crus-galli growing under mild drought condition showed a significant change and increased by 2.8 folds compared to the other which grown in native waterlogged habitat (table. 3 ). Mild drought caused a significant change in the spike WC which decreased by $23 \%$ compared to the other which grown in native waterlogged habitat. The present results indicated that E. crus-galli can adapt to anoxia as shown by the enhancement to spike growth and spike DW, while the sensitive crop plants to waterlogging showed decrease in yield (Dennis et al. 2000), approximately $11 \%$ of cotton yield was lost due to waterlogging and in severe cases it can reach to 40\% (Hodgson and Chan 1982).

When both E. crus-galli and E. colona were grown under mild drought (treatment 2), a significant decrease in leaf sheath length was detected $(21.4 \%$ and $21.0 \%$, respectively) compared to the other which grown in native waterlogged habitat, while when exposed to water-logging (treatment 4) did not show any significant change in E. crus-galli but a significant increase was present in E. colona by $38.98 \%$ compared to the other which grown in native aerobic habitat (Table.2). The increase in leaf sheath length of flooded plants resulted from a high number of longer parenchymatic cells compared to control plants (Insausti et al. 2001). Mild drought condition caused a significant change in leaf area of E. crus-galli, it decreased by $18.9 \%$ compared to the other which grown in native waterlogged habitat, but no significant change was found in E. colona. The reduced leaf area is a modification to avoid evopo-transpiration loss and to increase the efficient use of water in grasses which helps to tolerate water deficit. Kennedy et al. (1980) reported that Echinochloa spp. became troublesome weeds in paddy fields due to their ability to match the anoxia tolerance of rice in germination.

Transplanting of both E. crus-galli and E. colona under mild drought and water-logging conditions significantly decreased the PEPC protein level compared to those transplanted to native habitats, the decrease in PEPC level may affect the photosynthetic rate in plants, this protein acts as a primary physiological target of drought in photosynthesis (Lawlor 1995).

Rubisco protein level significantly decreased when both species were transplanted to aerobic conditions compared to the those transplanted to native waterlogging habitat, upon growing under water-logging conditions, the Rubisco protein level significantly increased compared to the other which grown in native aerobic habitat. Rubisco is the most abundant protein on the earth and contributes a high percentage of the total leaf nitrogen in C3 plants (Feller et al. 2008). It has been suggested that both the capacity for ribulose-1,5- bisphosphate (RuBP) regeneration and the carboxylation efficiency are substantially reduced under drought, and each of these processes has been proposed to be the main 
Khedr et al.

limitation to photosynthesis imposed by drought under saturating light and current atmospheric $\mathrm{CO}_{2}$ concentrations (Escalona et al. 1999).

PEPC/Rubisco ratio significantly increased when both plants exposed to mild drought condition compared to plants transplanted to native water-logging habitat, but significantly decreased under water-logging conditions compared to the other which grown in native aerobic habitat. The higher the ratio of PEPC/Rubisco the increasing plant growth and adaptation with drought is achieved. The ratio of PEPC to Rubisco activity in Amaranthus retroflexus (C4) ranged from four at low nitrogen content per area $(\mathrm{N})$ to seven at high $\mathrm{N}$. The fraction of organic $\mathrm{N}$ invested in carboxylation enzymes increased with increased $\mathrm{N}$. The fraction of $\mathrm{N}$ invested in Rubisco ranged from 10 to $27 \%$ in Chenopodium album (C3). In A. retroflexus, the fraction of $\mathrm{N}$ invested in Rubisco ranged from 5 to $9 \%$ and the fraction invested in PEPC ranged from 2 to 5\% (Sage et al. 1987). In general, PEPC/Rubisco ratio has been reported to be adjusted in order to minimize the leakage of $\mathrm{CO}_{2}$ from the bundle sheath (Kromdijk et al. 2008). Interspecific variation in PEPC/Rubisco ratio was also reported by Sharwood et al. (2016). The increase in PEPC/Rubisco ratio in E. crus-galli from wet habitat grown in semi-dry soil suggest an increased demand for primary $\mathrm{CO}_{2}$ fixation perhaps due to decreased availability of $\mathrm{CO}_{2}$ in the mesophyll cells. This could have resulted from restricted stomatal conductance as result of less water availability.

Some studies showed that the stimulation of leaf photosynthesis at elevated $\mathrm{CO}_{2}$ was not associated with changes in the ratio of activities of PEPC to Rubisco (Ziska et al. 1999). The $\mathrm{CO}_{2}$ effect on the photosynthetic biochemistry is largely mediated by carbohydrate accumulation in leaves under conditions where carbon sinks in the plant are also experiencing high carbon supply (Sage and McKown 2006). The effectiveness with which increases in $\mathrm{CO}_{2}$ can be translated into growth benefits is depending in the sink-source balance and is affected by various plant and environmental factors (Leakey et al. 2006)

Both Echinochloa species showed a considerable adaptation to aerobic and water-logged habitat. (Mitsch and Gosselink, 1986) reported that adaptation of C4 plants induces selective advantage in the wetlands. Because PEPC (plays a key role in C4 photosynthesis) and Rubisco is the main enzyme to Calvin cycle, so we studied the effect of both mild drought and water-logging on them. Adaptation of plants to water-logging helps to be good competitors in paddy fields with rice, this considered a great problem where these plants reduce rice yield.

In E. crus-galli, exposing the plants to mild drought upregulated new isozymes of peroxidase (P4) whereas, when exposed to water-logging POD isoforms did not affect. In E. colona, when the plants were exposed to mild drought and water-logging, this did not affect peroxidase isozymes where three bands of isozymes were present in all treatments (P1, P3 and P5). Abogadallah et al. (2010) reported that in the unstressed leaves of E. crus-galli just three high molecular weight isoforms (POD 1 through 3) were present. The present results of E. colona indicated that it was adapted with mild drought and water-logging, where it did not produce a new isoform or cause a decrease in normal isoforms under both mild drought and water-logging. In E. crus-galli, mild drought enhanced new isozymes although the plant seemed to adapt with water-logging. Contrasting to the previous data, that drought is known to limit the internal $\mathrm{CO}_{2}$ concentrations of leaves due to stomatal closure. This causes inhibition of $\mathrm{CO}_{2}$ reduction by Calvin cycle. Furthermore, limiting the internal $\mathrm{CO}_{2}$ concentration induces the oxygenase activity of Rubisco and increases in the rate of photorespiration. This leads to more production of $\mathrm{H}_{2} \mathrm{O}_{2}$ in the peroxisome (Van Breusegem et al. 2001). This could be the case in the present study. Plants produce reactive oxygen species "ROS" under Environmental stresses including waterlogging or drought further increase the production of ROS, which cause oxidative stress. ROS that cause oxidative stress include hydrogen peroxide $\left(\mathrm{H}_{2} \mathrm{O}_{2}\right)$, peroxidase "POD" decompose $\mathrm{H}_{2} \mathrm{O}_{2}$, also suggests that POD is involved in fine regulation of $\mathrm{H} 2 \mathrm{O} 2$ level (Mittler 2002). Parlanti et al. (2011) reported that two rice varieties, 'FR13A' and 'Arborio Precoce', showed different responses to 
Khedr et al.

submerging, a significantly increased level of $\mathrm{H}_{2} \mathrm{O}_{2}$ was detected in submerged ' $\mathrm{FR} 13 \mathrm{~A}$ ' leaf sheaths, while in 'AP' the $\mathrm{H}_{2} \mathrm{O}_{2}$ level was unchanged.

\section{Alcohol dehydrogenase $(A D H)$}

The transcript level of $A D H$ in E. colona was increased in treatments 2 and 4 compared to treatments 1 and 3, respectively. The expression of $A D H$ in E. crus-galli was only detectable in plants exposed to water-logging. Since $A D H$ null mutants were found to be more sensitive to water-logging, $A D H$ was considered essential for water-logging survival, because it recycles $\mathrm{NAD}^{+}$for continued glycolysis in the absence of oxygen (Rizal and karki 2011). Peng et al., 2001 reported that induction of $A D H$ gene was linked to ethylene production; also showed that hypoxic induction of $A D H$ could be inhibited by aminooxy-acetic acid, an inhibitor of ethylene biosynthesis. Altering the expression of various genes allows plants respond to stresses (Chaves et al. 2009). The induction of stress protein synthesis was also confirmed under ecological stresses including anaerobic one (Sachs et al. 1980). Anaerobic stress proteins have been characterized as glycolytic enzymes like alcohol dehydrogenase (Xie and Wu, 1989). It was reported that water-logging -intolerant Echinochloa species did not produce anaerobic proteins (Mujer et al. 1993). Rivoal et al. (1997) reported that $A D H$ gene and other fermentative genes were induced by hypoxia and water-logging. Dolferus et al. (1994) reported that the expression of $A D H$ in several plants was induced by osmotic stress.

The transcript level of $A D H$ in root was not detectable in both E. colona and E. crus-galli. In flood intolerant plants such as Arabidopsis and pea, increased $A D H$ activity was determined in the roots than in the shoots under anaerobic condition (Chung and Ferl 1999; Kato-Noguchi 2000), this confirmed that E. crus-galli and E. colona were tolerant to flooding. Roslan et al. (2008) who reported that a higher $A D H$ enzyme expression was observed in sago palm young shoots compared to the other part of Metroxylon sagu. Conley et al. (1999) reported that $A D H$ gene was expressed at extremely low levels in Arabidopsis cells under normal growth conditions and their expression was strongly induced by water-logging or hypoxia. The present study indicated that $A D H$ gene is expressed constitutively at a fairly high level under native habitats (aquatic and aerobic) then enhanced with reversing habitat that caused anoxic and mild drought conditions; this could mean the importance of $A D H$ to normal growth even without stress.

We conclude, based on the results of morphological traits, physiological analysis and expression of $A D H$, that both E. crus-galli and E. colona have great potential to adapt to changing habitats in terms of soil water status, where $A D H$ gene was expressed constitutively at a fairly high level under normal growth conditions (native aquatic and native aerobic habitat). Since both species are adapted to flooded fields and semi-dry conditions, this presents a challenge to the current and future efficacy of weed management.

\section{Acknowledgement}

The authors immensely grateful to Dr. Reham M. Nada for help with Biochemical and Molecular Analysis.

\section{References}

Abogadallah GM, Quick WP (2009) Vegetative salt tolerance of barnyard grass mutants selected for salt tolerant germination. Acta Physiol Plant. 31: 815-824.

Abogadallah GM, Serag MM, Quick WP (2010) Fine and coarse regulation of reactive oxygen species in the salt tolerant mutants of barnyard grass and their wild-type parents under salt stress. Physiol. Plan. 138: 60-73.

Armstrong W (1979) Aeration in higher plants. Adv Bot Res 7: 225-332. 
Khedr et al.

Bradford MM (1976) A rapid and sensitive method for the quantitation of microgram quantities of protein utilizing the principle of protein-dye binding. Anal Bioch. 72: 248-254.

Bray EA, Bailey-Serres J, Weretilnyk E (2000) Responses to abiotic stresses, in: B.B. Buchanan, W. Gruissem, R.L. Jones (Eds.) Biochem \& Mol. Biol. Plant, Am. Soc. P. Physiol, Rockville, Maryland. Pp. 1158-1203.

Cannell RQ, Belford RK, Gales K, Dennis CW, Prew RD (1980) Effects of water logging at different stages of development on the growth and yield of winter wheat. J. Sci. Food Agric. 31: 117-132.

Chang C, Meyerowitz EM (1986) Molecular cloning and DNA sequence of the Arabidopsis thaliana alcohol dehydrogenase gene. Proc. Nati. Acad. Sci. USA. 83:1408-1412.

Chaves MM, Flexas J, Pinheir C (2009) Photosynthesis under drought and salt stress: regulation mechanisms from whole plant to cell. Ann. Bot. 103: 551-560.

Chung HJ, Ferl RJ (1999) Arabidopsis alcohol dehydrogenase expression in both shoots and roots is conditioned by root growth environment. Plant Physiol. 121: 429-436.

Conley TR, Peng HP, Shih MC (1999) Mutations affecting induction of glycolytic and fermentative genes during germination and environmental stresses in Arabidopsis. Plant Physiol. 119: 599 - 607.

Crawford RMM (1977) Tolerance of anoxia and ethanol metabolism in germinating seeds. New Phytol. 79: $511-517$.

Dennis ES, Dolferus R, Ellis M, Rahman M, Wu Y, Hoeren FU, Grover A, Ismond KP, Good AG, Peacock WJ (2000) Molecular strategies for improving waterlogging tolerance in plants. J. Exp. Bot. 51: 89-97.

Dolferus R, Jacobs M, Peacock W, Dennis E (1994) Differential interactions of promoter elements in stress responses of the Arabidopsis Adh gene. Plant Physiol. 105: 1075-1087.

Escalona JM, Flexas J, Medrano H (1999) Stomatal and non-stomatal limitations of photosynthesis under water stress in field-grown grapevines. - Aust. J. Plant Physiol. 26: 421-433.

Feller U, Anders I, Mae T (2008) Rubiscolytics: fate of Rubisco after 1st enzymatic function in a cell is terminated. J. Exp. Bot. 59:1615-1624.

Heydarian Z, Sasidharan R, Cox MCH, Pierik R, Voesenek LACJ, Peeters AJM (2010) A kinetic analysis of hyponastic growth and petiole elongation upon ethylene exposure in Rumex palustris. Ann. Bot. 106: 429-435.

Hodgson AS, Chan KY (1982) The effect of short-term waterlogging during furrow irrigation on cotton in a cracking grey clay. Aust. J. Agr. Res. 33: 109-116.

Holm LG, Plucknett DL, Pancho JV, Herberger JP (1977) Echinochloa crus-galli (L.) Beauv. In: The world's worst weeds. Honolulu, HI, USA: University Press of Hawaii. pp 32- 40.

Holm LG, Plucknett DL, Pancho JV, Herberger JP (1991) The World's Worst Weeds: Distribution and Biology. Malabar, Florida: The University Press of Hawaii. Pp. 609-612.

Insausti P, Grimoldi AA, Chaneton EJ, Vasellati V (2001) Flooding induces a suite of adaptive plastic responses in the grass Paspalum dilatatum. New Phytol. 152: 291-299.

Kato-Noguchi H (2000). Osmotic stress increases alcohol dehydrogenase activity in maize seedlings. Biol. Plan. 43: 621-623.

Keeley JE, Franz EH (1979) Alcoholic fermentation in swamp and upland populations of Nyssa sylvatica: temporal changes in adaptive strategy. Am. Nat. 113: 587-592.

Kemp CD (1960) Methods of estimating the leaf area of grasses from linear measurements. -Ann. Bot. 24: 491-499.

Kennedy RA, Barret SC, Vander Zee D, Rumpho ME (1980) Germination and Seedling Growth under Anaerobic Conditions in Echinochloa crus-galli (Barnyard Grass). Plant Cell Environ. 3: 243-248.

Kromdijk J, Schepers HE, Albanito F, Fitton N, Carroll F, Jones MB, Finnan J, Lanigan GJ, Griffiths $\mathrm{H}$ (2008) Bundle sheath leakiness and light limitation during $\mathrm{C} 4$ leaf and canopy $\mathrm{CO}_{2}$ uptake. Plant Physio. 148: 2144-2155.

Laemmlli EK (1970) Cleavage of structural proteins during the assembly of the head of bacteriophage T4. Nature. 227: 680-685.

Lawlor DW (1995) The effects of water deficit on photosynthesis. In: Smirnoff N, ed. Environment and Plant Metabolism. Flexibility and Acclimation. Oxford, UK. BIOS Sci. Pub. Pp. 129-160.

Leakey ADB , Uribelarrea M, Ainsworth EA, Naidu SL, Rogers A, Ort DR, Long SP (2006) Photosynthesis, productivity, and yield of maize are not affected byopen-air elevation of $\mathrm{CO} 2$ concentration in the absence of drought. Plant Physiol. 140:779-790. 
Khedr et al.

Linhart YB, Grant MC (1996) Evolutionary significance of local genetic differentiation in plants. Ann. Rev. Ecol. Syst. 27:237-277.

Maun MA, Barrett SC (1986) The biology of Canadian weeds. 77. Echinochloa crus galli (L.) Beauv. Can. J. Plant Sci. 66:739-759.

Mercado BL, Talatala RL (1977) Competitive ability of Echinochloa colonum L. against direct-seeded lowland rice. In Proceedings of the Sixth Asian-Pacific Weed Science Society Conference. Jakarta, Indonesia: Indonesia Asia-Pacific Weed Science Society. Pp.161-165.

Mitsch WJ, Gosselink JG (1986) Wetlands. Van Nostr and Reinhold Company, New York. Pp. 539.

Mittler R (2002) Oxidative stress, antioxidants and salt tolerance. Trends Plant Sci 7: 405-410

Mujer CV, Rumpho VE, Lin JJ, Kennedy RA (1993). Constitutive and inducible aerobic and anaerobic stress proteins in Echinochloa complex and rice. Plant Physiol. 101: 217-226.

Parlanti S, Kudahettige NP, Lombardi L, Mensuali-Sodi A, Alpi A, Perata P, Pucciariello C (2011) Distinct mechanisms for aerenchyma formation in leaf sheaths of rice genotypes displaying a quiescence or escape strategy for flooding tolerance. Ann. Bot. 107: 1335-1343.

Peng HP, Chan CS, Shih MC, Yang SF (2001) Signaling events in the hypoxic induction of alcohol dehydrogenase gene in Arabidopsis. -Plant Physiol. 126: 742-749.

Rao AN, Johnson DE, Sivaprasad B, Ladha JK, Mortimer AM (2007) Weed management in directseeded rice. Adv. Agron. 93: 153-255.

Rivoal J, Thind S, Pradet A, Ricard B (1997) Differential induction of pyruvate decarboxylase subunits and transcripts in anoxic rice seedlings. Plant Physiol. 114: 1021-1029.

Rizal G, Karki S (2011) Alcohol dehydrogenase (ADH) activity in soybean (Glycine max [L.] Merr.) under flooding stress. Electron. J. Plant Bree. 2:50-57.

Roslan HA, Sundaraj Y, Husaini AASA (2008) Multiple forms of alcohol dehydrogenase (Adh) genes in sago palm: a preliminary study BANWA. vol. 5 , no. 1.

Sachs MM, Freeling M, Okimoto R (1980) The anaerobic proteins of maize. Cell. 20: 761-767.

Sage RF, McKown AD (2006) Is C4 photosynthesis less phenotypically plastic than C3 photosynthesis? J. Exp. Bot. 57: No. 2 303-317.

Sage RF, Pearcy RW, Seemann JR. (1987) The Nitrogen Use Efficiency of C3 and C4 Plants "III. Leaf nitrogen effects on the activity of carboxylating enzymes in Chenopodium album (1.) and Amaranthus retroflexus (L.)". Plant Physiol. 85: 355-359

Schlichting CD, Pigliucci M (1998) Phenotypic evolution: a reaction norm perspective. Sinauer Assoc. Inc. Sunderland, MA. Pp. 387.

Seevers FM, Daly JM, Catedral FF (1971) The role of peroxidase isozymes in resistance to wheat stem rust. Plant Physiol. 48: 353-360.

Shafqat J, El-Ahmad M, Danielsson O, Martinez MC, Persson B, Parés X and Jörnvall H (1996) Pea formaldehyde-active class III alcohol dehydrogenase: common derivation of the plant and animal forms but not of the corresponding ethanol-active forms (classes I and P). Proc Natl Acad Sci USA 93: 5595-5599.

Sharwood RE, Sonawane BV, Ghannoum O, Whitney SM (2016) Improved analysis of C4 and C3 photosynthesis via refined in vitro assays of their carbon fixation biochemistry. J Exp Bot. 67: 31373148.

Striker GG (2012) Flooding stress on plants: anatomical, morphological and physiological responses, Botany, Dr. John Mworia (Ed.), ISBN: 978-953-51-0355-4.

Taji T, Seki M, Satou M, Sakurai T, Kobayashi M, Ishiyama K, Narusaka Y, Narusaka M, Zhu JK, Shinozaki K (2004) Comparative genomics in salt tolerance between Arabidopsis and Arabidopsisrelated halophyte salt cress using Arabidopsis microarray. Plant Physiol. 135: 1697-1709.

Van Breusegem F, Vranova E, Dat JF, Inz'e D (2001) The role of active oxygen species in plant signal transduction. Plant Sci. 161: 405-414.

Vidotto F, Tesio F, Tabacchi M, Ferrero A (2007) Herbicide sensitivity of Echinochloa spp. accessions in Italian rice fields. Crop Pro. 2:285-293

Xie Y, Wu R (1989) Rice alcohol dehydrogenase genes: anaerobic induction, organ specific expression and characterization of cDNA clones. Plant Mol Biol. 13: 53-68.

Ziska LH, Sicher RC, Bunce JA (1999) The impact of elevated carbon dioxide on the growth and gas exchange of three $\mathrm{C} 4$ species differing in $\mathrm{CO} 2$ leak rates. Physiol Plan. 105: 74-80. 